\title{
Social Instincts as Regulators of the Current Stage of the Earth's Evolution
}

\author{
VA Dementiev* \\ V Vernadsky Institute of Geo- \& Analytical Chemistry RAS, Moscow, Russia \\ *Corresponding author: VA Dementiev, V Vernadsky Institute of Geo- \& Analytical Chemistry RAS, Moscow, Russia
}

ARTICLE INFO $\quad$ ABSTRACT

Received: 蔧 March 22, 2021

Citation: VA Dementiev. Social Instincts as Regulators of the Current Stage of the Earth's

Published: 幽 April 01, 2021

\section{Short Communication}

Nature has generously endowed one of the species she has created. As a result of the evolutionary development of the species Homo sapiens, its more successful species, Homo sapiens, acquired intelligence. Note that this gift is able to manifest itself in an arbitrarily small society and become the engine of the evolution of the noosphere. This is how the small Jewish people developed the idea of one God. This put an end to the pantheistic religions of the ancient Mediterranean forever. Occasionally a genius becomes such an engine if he is born in a suitable social atmosphere. Such were Galileo, Newton, Bohr, Vernadsky. Niels Bohr discovered that reason as a natural phenomenon cannot fully embrace natural laws. And here Nature again took care of the species Homo sapiens. She provided him with instincts so that in difficult situations an individual or society would act apart from reason. From the rich set of instincts, we single out two: the instinct of curiosity and the instinct of self-destruction. We note that the noted instincts do not play any role in the evolution of the Earth if they are manifested in an individual. A child-mowgli is curious only for the sake of meager food. This will not lead to the accumulation of knowledge in libraries. But large societies, observing the life of plants in the area of Mesopotamia, have found a way to feed not only themselves, but also for Canada. Let us remember that there was a time when Canada sent grain to the USSR. Now Russia is sending grain to Turkey and Egypt.

An individual with a damaged psyche can self-destruct by jumping out of the window shouting "The Russians are coming!" This will not affect the evolution of the Earth in any way. But large societies, rubbing against each other (the forces of attraction- repulsion are the driving forces of evolution [1]) and irritated by these frictions, decide it is time to liquidate the neighboring society (tribe, ethnos, country, civilization). As a result, the populations of rubbing societies are significantly reduced. Thinning and weeding of the populations of the species Homo sapiens takes place. This noticeably affects the development of planet Earth. Physicists deal with the simplest phenomena in the material world and believe that fundamental forces do not set themselves any goals. Biologists, on the other hand, deal with the most complex manifestations of these forces in the living world. It is convenient for biologists to think that living matter has goals: survival, quantitative and evolutionary development. A physicist, working in close contact with biologists, asks a natural question - for what purpose did living matter provide the species Homo sapiens with the instinct of self-destruction? Why does humanity need war? The author of these notes tried to find an answer to this fundamental question. To begin with, he asked an auxiliary question from Roman law - who benefits?

Having familiarized himself with the history of wars, the physicist concluded that in no war, not one of the belligerent parties received long-term benefits for themselves. Rome was building its mighty empire, regularly going out to the next war strictly on March 1. But the empire split into western and eastern parts, and then both parts of the empire were defeated in local wars. The Spanish colonial conquests brought a lot of gold to the country. But from both Spains, which could have been successfully ruled by the barber Figaro, nothing powerful remained. Germany's attempts to turn into a colonial empire by unleashing two world wars ended in Germany's transformation into a location for the US nuclear potential. Having familiarized himself with the history of 
the emergence and disappearance of species in the biosphere of the Earth, the physicist was not upset about the disappearance of some species, since death is a necessary condition for the appearance and existence of life [2]. But physics was confused by the calculations of Vernadsky, who showed that the production of entropy on the planet Earth (this is an indicator of the degradation of all systems of the planet) is caused in equal shares by three processes: geological, biosphere and human activity. As a result, the author had a hypothesis that Nature, in caring for all her creatures, was confused by the power of the destructive capabilities of Mankind.

Man destroys mountain systems in order to extract iron and destroyed several species in the biosphere. In order to limit these possibilities, Nature has invented viral and other infections designed to thin out our populations. But this invention was not very effective. An inquisitive species has learned to resist epidemics and even pandemics. Nature is left to rely on the self-destruction instinct incorporated in man, which manifests itself in large societies in the form of a continuous desire for wars. The history of war, which shows the evolutionary development of means of warfare, speaks in favor of the validity of this assumption. Homo inquisitive invents all the new tools for earning a livelihood. In humanity, a genetic memory of these events arises in order to reproduce such instruments [3]. Homo militant adapts suitable tools (ax, gunpowder, artificial fission of uranium) to reduce populations on Earth. At the same time, he is extremely unhappy when they try to limit his activity. No sooner had the presidents of the United States and Russia reached an agreement on the extension of the START3 treaty, than Great Britain announced that it was building up its nuclear potential. If things go on like this, then the species Homo sapiens can be erased from the face of planet Earth. Then no one interferes with the development of cockroaches that can survive in conditions of radiation. Biomedical Journal of Scientific \& Technical Research is an interdisciplinary publication.

Hence, the hope arises that the authors and readers of the journal will join efforts and help psychiatrists develop a methodology for influencing representatives of the militant Homo species. This may require the creation of social psychiatry. This will allow humanity to limit the manifestations of the self-destruction instinct. Some hope for this is given by the experience of the US leaders, who limited themselves to the destruction of the population of only two cities in just Japan. And then the United States deliberately abandoned the destruction of Russian cities when inquisitive Russian scientists and engineers prepared nuclear weapons capable of destroying the United States. It is funny that the author tried to publish this hypothesis back in 1982. Then his manuscript was reviewed in two offices - in the KGB and in the General Staff of the USSR. It was decided not to publish the article and not to arrest the author. Let him ponder the problem further, but in splendid isolation. And for general use there is a book "The Marxist Philosophy of War". This is enough for the citizens of the USSR.

\section{References}

1. VA Dementiev (2014) The Driving Forces of Evolution. Geochemistry International 52(13): 1146-1189.

2. VA Dementiev (2020) How to: The origin of life or the rise of life and death? Biomedical Journal of Scientific \& Technical Research 26(1).

3. VA Dementiev The Formation of Genetic Memory at Various Stages of the Evolution of the Earth. Journal of Current Trends in Physics Research and Applications 1(1): 107.

\section{ISSN: 2574-1241}

DOI: $10.26717 /$ BJSTR.2021.34.005626

VA Dementiev. Biomed J Sci \& Tech Res

(C) This work is licensed under Creative Commons Attribution 4.0 License

Submission Link: https://biomedres.us/submit-manuscript.php

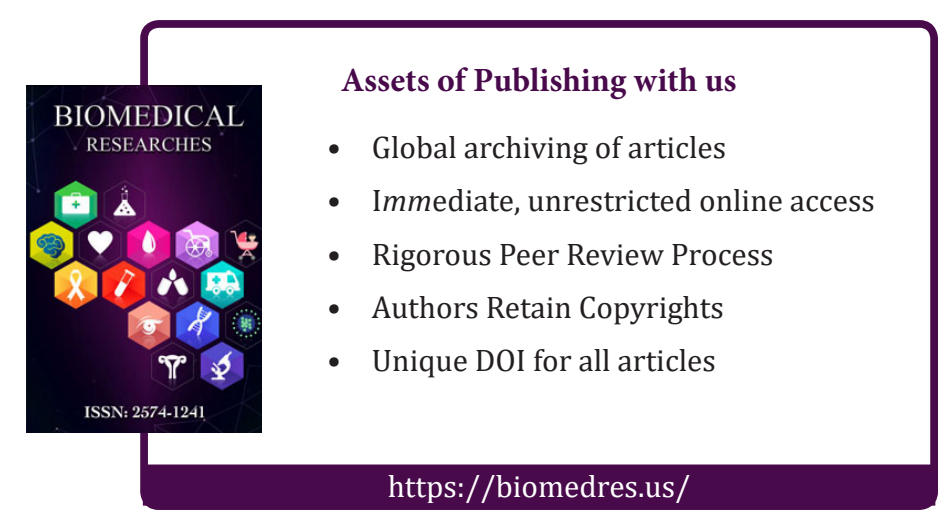

